\title{
A Market Study of Organic Food and Products Available in Hyderabad City, India
}

\author{
Anoushka Darga ${ }^{1 *}$ and Ashlesha Pendli ${ }^{2}$ \\ Department of Food and Nutrition, University College for Women, Koti, Hyderabad, India \\ *Corresponding author
}

Keywords

Organic food, Market survey, Cost of organic food, Cost comparison, Conventional Vs organic food, Organic food certification

Article Info

Accepted:

04 May 2019

Available Online:

10 June 2019
The present study was conducted in the market of Hyderabad city to know the present condition of organic food market. Data was collected with the help of structured and duly pre tested interview schedule. Data was also collected regarding the price range of 50 products from 5 organic and 5 conventional stores. Result reveals that there were five main outlets online and offline that were majorly selling organic food and products range. The main aim of this study was to explore present market scenario and the major factors responsible for future growth of the organic food products business in the city. Since, there is a tremendous change in the last few years in the awareness of the consumers, this study helps the consumers to know the types of products and also compare the average cost of organic food to the conventionally produced food.

\section{Introduction}

Agriculture has been the backbone of our nation. From the time of introduction of green revolution and methods to increase the yield of the crop, farmers in India have been put into a state of mind that the greater fertilizers and pesticides that are used, the greater is the yield where the truth is, the yield cannot be increased by just the addition of the chemicals to the crop but the farming techniques, water supply, weed removal and the quality of the seed play a major role too. No doubt green revolution has helped to increase the food production and immensely saved lives during the time of food crisis while helping India become self-sufficient in this aspect but the farmers need to be educated about the abuse of the chemicals for food production.

The pesticides, insecticides, fertilizers that the farmers may use in excess in view of higher food production, may get embedded into the cell structure of the food and will not be 
washed away. This deposition of chemicals that happens unknowingly will get transferred into the body of the animal/ human consuming it and this repetitive deposition is termed as pesticide residue.

Pesticide residue may induce adverse health effects including cancer, effects on reproduction, immune or nervous systems. Scientific studies of the potential health effects of hazardous chemicals, such as pesticides, allow them to be classified as

- carcinogenic (can cause cancer),

- neurotoxic (can cause damage to the brain), or - teratogenic (can cause damage to a foetus).

Deshmukh and Babar (2015) revealed that India's total area under organic certification was 4.72 million hectare in 2013-14 and its global rank is 10th. The crop growth rate of cultivation of organic area of India was $11.52 \%$ of which wild collection was $12.57 \%$ and remaining area was $7.45 \%$ during 2005 2013. The co-efficient of variation was approximately $0.5 \%$ during same period. Compound growth rate of export quantity of organic products of India was $51.50 \%$ and export value was $11.75 \%$ during 2002-03 to 2013-14. Among all the States in India, Uttar Pradesh has highest area under organic farming followed by Himachal Pradesh, Madhya Pradesh and Maharashtra in 2011-12. India exports around 135 organic products of which the share of oil crops in total organic export quantity was $(26.74 \%)$ followed by cotton $(24.48 \%)$, basmati rice $(11.81 \%)$ in 2013-14. India is exporting organic products to all the continents of the world of which the largest share goes to EU (44.12\%) followed by USA $(19.2 \%)$.

As per the survey, in Spain consumers are still adjusting with the higher prices of organic food and they are willing to pay similar to the existing prices (Sanjuan et al., 2003).
Organic food consumers give less importance to price as compared to the consumers who never purchase organic food earlier (Williams et al., 2001).

The premium prices for organic food are justified by the food safety, taste and nature conservation. Few of the consumers feel that they have to pay higher price for healthier food and some consumers simply assume that organic food is not affordable (Hamm et al., 2002).

As per the Food and Agriculture Organization (FAO) report, 14000 tonnes of organic food produce is from certified organic farms in India. But there are more organic farm areas than mentioned by FAO. Sometimes Organic food is not recognized though it has been grown in organic farms as farmers have not registered their name nor paid the registration charges for official certification (Shetty et al., 2013).

Organic farming is a production system that sustains the health of soils, ecosystems and people. It relies on ecological processes, biodiversity and cycles adapted to local conditions, rather than the use of inputs with adverse effects. Organic farming combines tradition, innovation and science to benefit the shared environment and promote equitable relationships and a good quality of life for all involved. In other words, organic agriculture aims to produce healthy and quality foods without using synthetic chemical products. Thus, organic agriculture not only preserves the environment but it also improves public health, bringing significant benefits both to the economy as well as to the social cohesion of rural areas (IFOAM, 2012; de Magistris and Gracia, 2008; Falguera et al., 2012). Nonavailability of organic food in the store is one of the most important barriers for consumer's purchasing (Davies et al.,, 1995). 
The consumer attitude is highly unfavourable towards organic food due to availability and price (Silverstone, 1993).

The study shows that still there is the need of more number of certified organic shops in market. The market of organic food is just handful and need to be promoted by the government among farmer (producer) and consumer so that a profitable business can be run successfully (Nayana Sharma and Ritu Singhvi).

\section{Materials and Methods}

The study was conducted in Hyderabad, Telangana. During the market survey researcher found that there were five outlets which where exclusively selling majority of organic food and products. They were selected on the basis of popularity and frequency of purchase by the consumers. Some of the outlets have a website that provides home delivery of goods.

The brands that were selected for the market survey of organic products are as follows:

Sahaja Aharam

24 Organic Mantra

Pro nature

Organic tattva and

Terra Greens

The brands that were selected for the market survey of conventionally produced food are as follows:

\section{Ratnadeep \\ D-Mart \\ More \\ Big Basket \\ Groffers}

The researcher herself visited each offline shop selected as a sample for market survey and collected data with the help of developed interview schedule with the shopkeeper. The collected data was tabulated. The data collected from market survey was coded and decoded to formulate the comprehensive tables. The responses were analysed using frequencies. The tabulated form of the data collected is given in table 1 and 2 .

\section{Results and Discussion}

Market survey of 50 products from 10 brands, 5 of which were the brands that produced food organically while the other 5 were the brands that produced food by the conventional methods. The market survey was conducted in order to assess the availability of various products among the organic stores and also to compare the availability of products between stores that have food produced organically and the stores that had food produced food by the conventional methods.

The table 1 shows the average price range of the products collected during the market survey: During the market survey, 6 aspects were observed and tabulated in table 2 . They can be broadly divided into 2 aspects based on type of products and certification. It was done to obtain a clear idea of the products available at the organic stores.

Under type of products, the stores were observed if they had only organic food products or Organic as well as non organic food products or Organic food products with other organic products like organic clothing and organic beauty products. Under the category of certified products, the stores were observed if they sold Solely certified organic food products or Few organic items with certification and few organic items without organic certification or Organic food products without certification. 
Table.1 List of the products consolidated with cost

\begin{tabular}{|c|c|c|}
\hline PRODUCTS & \multicolumn{2}{|c|}{ STORES } \\
\hline FLOURS \& CEREALS (1Kg) & $\begin{array}{l}\text { ORGANIC FOOD STORES } \\
\text { (price in rupees) }\end{array}$ & $\begin{array}{l}\text { STORES WITH CONVENTIONAL } \\
\text { FOOD (price in rupees) }\end{array}$ \\
\hline Wheat Flour & $60-75$ & $26-46$ \\
\hline White Jowar Flour & $75-126$ & $60-80$ \\
\hline Yellow Jowar Flour & 80 & 59.5 \\
\hline Rice Flour & $75-118$ & $40-60$ \\
\hline Ragi Flour & $80-120$ & $42-90$ \\
\hline Multigrain Flour & 135 & $52-86$ \\
\hline Bengal gram Flour & $122-230$ & $82-130$ \\
\hline Bajra Flour & $60-98$ & $42-80$ \\
\hline Rice, SonaMasoori (1Kg) & $68.8-99$ & $45.5-58$ \\
\hline Rice,Brown & $76.2-99$ & $45--150$ \\
\hline \multicolumn{3}{|c|}{ PULSES (1Kg) } \\
\hline Bengal Gram dal (whole) & $115-330$ & $102-180$ \\
\hline Bengal Gram dal (split) & $148-198$ & $86-140$ \\
\hline Toor Dal & $107-160$ & $86-109.5$ \\
\hline Green Gram dal(whole) & 144-198 & $97-140$ \\
\hline Green Gram dal(split) & $153-198$ & $102-124$ \\
\hline Cow Pea & $142-160$ & $64-150$ \\
\hline Black Gram Dal (whole) & $150-188$ & $80-120$ \\
\hline Black Gram Dal (split) & $130-210$ & $73-124$ \\
\hline Bengal Gram whole (black) & $110-144$ & $86-120$ \\
\hline Rajma & 184 & \\
\hline \multicolumn{3}{|c|}{ MILLETS (1Kg) } \\
\hline Ragi Whole & $68-116$ & $45-100$ \\
\hline White Jowar & 75 & $45-66$ \\
\hline Yellow Jowar & $80-84$ & - \\
\hline Barnyard Millets/Udalu & $145-228$ & $100-120$ \\
\hline Korra Whole/Foxtail Millet & $118-226$ & $90-120$ \\
\hline Kodo Millet Rice/ Arikelu & $154-226$ & $108-140$ \\
\hline Bajra Whole & $60-90$ & $36-55$ \\
\hline Sama Whole/Little millets & $120-226$ & $108-140$ \\
\hline \multicolumn{3}{|c|}{ SPICES \& CONDIMENTS (50gm) } \\
\hline Cardamon & $164-209$ & $112.5-297.5$ \\
\hline Mustard & $12.5-30$ & $11-13$ \\
\hline Red chillies & $15-27.5$ & $12-17$ \\
\hline Corriander Powder & $15.5-31.5$ & $11.5-26$ \\
\hline Chilli Powder & $16-27.5$ & $8.4-29$ \\
\hline
\end{tabular}




\begin{tabular}{|c|c|c|}
\hline Turmeric Powder & $16-22.5$ & $10.5-29$ \\
\hline Ajwain(vamu) & $27.5-30$ & $17-35$ \\
\hline Coriander Seeds & $9-45$ & $16.5-29.6$ \\
\hline Black Pepper & $82-110$ & $37-90$ \\
\hline Cumin (zeera) & $26-32.5$ & $37-48$ \\
\hline Cinnamon & $40-85$ & $48-200$ \\
\hline Cloves (Lavanga) & $140-180$ & $15-19$ \\
\hline Salt (1Kg) & $19-85$ \\
\hline & OILS (1)t) \\
\hline & $366-450$ \\
\hline Sesame Oil & $325-354$ \\
\hline Groundnut Oil & 294 & $316-351$ \\
\hline Sunflower Oil & $580-1450$ & $123-150$ \\
\hline Saff flower Oil & & $89-103$ \\
\hline Virgin Coconut Oil (500ml) & - \\
\hline & OIL SEEDS (100gm) & $400-750$ \\
\hline & $16.2-60$ & $27-34$ \\
\hline Sesame seeds & $16.6-24$ & $11.1-19$ \\
\hline Groundnut & $27.5-50$ & $14-31$ \\
\hline Flax seeds & $94-126$ & $35-45.8$ \\
\hline Sugar (1Kg) & & \\
\hline \hline
\end{tabular}

Table.2 Type and certified food products sold

\begin{tabular}{|c|c|c|c|c|c|c|}
\hline \multicolumn{2}{|r|}{$\begin{array}{l}\text { Pro } \\
\text { ducts }\end{array}$} & $\begin{array}{l}\text { SAHAJA } \\
\text { AHARAM }\end{array}$ & $\begin{array}{l}24 \\
\text { ORGANIC } \\
\text { MANTRA }\end{array}$ & $\begin{array}{l}\text { PRO } \\
\text { NATURE }\end{array}$ & $\begin{array}{l}\text { ORGANIC } \\
\text { TATTVA }\end{array}$ & $\begin{array}{l}\text { TERRA } \\
\text { GREENS }\end{array}$ \\
\hline \multicolumn{3}{|l|}{ A. } & \multicolumn{3}{|l|}{ Type } & \\
\hline 1. & Only organic food products & - & YES & YES & YES & - \\
\hline 2. & $\begin{array}{l}\text { Organic as well as non organic } \\
\text { food products }\end{array}$ & - & - & - & - & - \\
\hline 3. & $\begin{array}{l}\text { Organic food products with other } \\
\text { organic products like organic } \\
\text { clothing and organic beauty } \\
\text { products }\end{array}$ & YES & - & - & - & YES \\
\hline \multicolumn{3}{|c|}{ קе } & \multicolumn{3}{|c|}{ Certified products } & \\
\hline 1. & $\begin{array}{l}\text { Solely certified organic food } \\
\text { products }\end{array}$ & YES & YES & YES & YES & - \\
\hline 2. & $\begin{array}{l}\text { Few organic items with } \\
\text { certification and few organic } \\
\text { items without organic } \\
\text { certification }\end{array}$ & - & - & - & - & YES \\
\hline 3. & $\begin{array}{l}\text { Organic food products } \\
\text { without certification }\end{array}$ & - & & - & - & - \\
\hline
\end{tabular}

It was found that 3 out of the 5 survey stores had only organic food products. None of the store had organic as well as non organic food products and 2 out of 5 stores had Organic food products with other organic products like organic clothing and organic beauty products. Under the category of certified products, it was seen that 4 out of 5 stores had Solely 
certified organic food products. 1 out of 5 stores had few organic items with certification and few organic items without organic certification and none of the stores had organic food products without certification.

Market survey revealed that the gap between the price range of conventionally produced food and organic food is very pronounced and could be one of the major reasons why the majority of the population avoids the purchase of organic food and products.

The market survey also revealed that the 5 organic products brands that were selected for the survey, had the necessary certification done and were approved by India organic, USDA organic, Non- EU Agriculture, Control union etc.

\section{Acknowledgements}

I would like to express my gratitude and heartfelt thanks to my thesis guide Dr. (Mrs.) P. Ashlesha, Ph D. at University College for Women, Koti. I am immensely grateful to Dr. ROJA RANI, Principal, University College for Women, Koti and Dr. SARITHA REDDY, Vice Principal, University college for Women, Koti. I am very grateful to Mrs. Suma, Head of Dept. of Food \& Nutrition for her constant encouragement and support.

\section{References}

1.Deshmukh, M.S. and Babar, N. 2015. Present status and prospects of organic farming in India. Eur. Acad. Res. 3:
4271-4287.

2. IFOAM, 2012; de Magistris and Gracia, 2008; Falguera et al., 2012.

3. Sanjuan AI, Sanchez M, Gil JM, Gracia A, Soler F. Brakes to organic market enlargement in Spain: Consumers' and retailers' attitudes and willingness to pay. International Journal of Consumer Studies.2003; 27(2): 134-44.

4. Williams PRD, Hammitt JK, Perceived risks of conventional and organic produce: pesticides, pathogens, and natural toxins. Risk Analysis an International of European experience with shore nourishment. Coastal Engineering. 2002; 47(2):237-64.

5.Hamm L, Capobianco M, Dette HH. Lechuga A, Spanhoff R, Stive MJH. A Summary IFOAM, 2012; de Magistris and Gracia, 2008; Falguera et al., 2012.

6.Shetty PK, Hiremath MB, Murugan M. Status of organic farming in agro ecosystem inIndia. Indian Journal of Science and Technology. 2013; 6(8): pg 5083-8.

7.Davies A, Titterington AJ, Cochrane C. Who buys organic food? A profile of the purchasers of organic food in Northern Ireland. British Food Journal. 1995; 97(10): Pp. 17-23.

8.Silverstone R. Organic farming: Food for the future? Nutrition and Food Science. 1993, 93(5): 10-4.

9.Nayana Sharma and RituSinghvi. 2018. A Market Study of Organic Food Products Available in Udaipur City. Int.J.Curr.Microbiol.App.Sci. $\quad 7(08)$ : 845-856.

\section{How to cite this article:}

Anoushka Darga and Ashlesha Pendli. 2019. A Market Study of Organic Food and Products Available in Hyderabad City, India. Int.J.Curr.Microbiol.App.Sci. 8(06): 274-279. doi: https://doi.org/10.20546/ijcmas.2019.806.031 